\title{
RECENT DESICCATION-RELATED ECOSYSTEM CHANGES AT LAKE ABERT, OREGON: A TERMINAL ALKALINE SALT LAKE
}

\author{
Ron Larson ${ }^{1}$, Joseph Eilers ${ }^{2}$, Keith Kreuz ${ }^{3}$, Wolf T. Pecher ${ }^{4,7}$, \\ Shiladitya DasSarma ${ }^{5,7}$, and Steve Dougill 6
}

\begin{abstract}
AвsTRACT.—Lake Abert, a terminal alkaline salt lake in south central Oregon, has been a key staging area for migratory waterbirds along the Pacific Flyway. In 2014, the lake shrank to about 5\% of its maximum size, and its salinity increased from $75 \mathrm{~g} \cdot \mathrm{L}^{-1}$ to $250 \mathrm{~g} \cdot \mathrm{L}^{-1}$. This resulted in a major ecosystem shift from one dominated at higher trophic levels by invertebrates and waterbirds to one composed primarily of hypersaline-adapted microbes. A large variety of halophilic bacteria and archaea were also detected using 16S rRNA metagenomic sequence analysis. The loss of prey and staging habitat for migratory waterbirds was especially pronounced for Eared Grebe, Red-necked Phalarope, and Wilson's Phalarope, all of which feed on brine shrimp and alkali flies. The last time the lake was in this state was nearly a century ago during the Dust Bowl of the 1930s, which was a once-in-500-years drought. To understand the causes of the current event, we examined hydrological, climatic, and biological data. The primary cause of the event appears to have been the combined effects of upstream water diversions and lower river flows that were exacerbated by a moderate decade-long drought and elevated evaporation rates.
\end{abstract}

Resumen.-El Lago Abert, un terminal, lago alcalino-sal en el centro-sur de Oregon es un área de ensayo clave para las aves acuáticas migratorias a lo largo de la ruta migratoria del Pacífico. En 2014, el lago se redujo a aproximadamente $5 \%$ de su tamaño máximo, y su salinidad aumentó de $75 \mathrm{~g} \cdot \mathrm{L}^{-1}$ a $250 \mathrm{~g} \cdot \mathrm{L}^{-1}$. Esto se resultó en un sustancial cambio en el ecosistema de una dominada a mayores niveles tróficos por invertebrados y aves acuáticas a una compuesta principalmente de microbios hipersalino-adaptados. Una gran variedad de bacterias halófilas y arqueas también se detectó utilizando ARNr 16S secuencia análisis metagenómica. La pérdida de presas y hábitat de escenificación para las aves acuáticas migratorias fue especialmente pronunciada para las poblaciones de zampullín cuellinegro y de falaropo picofino y falaropo de Wilson, que se alimentan de artemia y moscas alcalinos. La última vez que el lago estaba en este estado era casi un siglo atrás durante la era Dust Bowl de los años 1930, una sequía de 500 años. Para entender las causas del suceso examinamos datos hidrológicos, climáticos y biológicos. La causa principal del evento parece haber sido los efectos combinados de las desviaciones de agua del río arriba y caudales del río más bajo, que fueron exacerbados por una sequía moderada que duraba una década y tasas de evaporación elevadas.

Worldwide, terminal lakes are at risk because climate change and upstream water diversions for agriculture have reduced inflows and increased salinity (Williams 2000, Micklin 2007, Jellison et al. 2008, Herbst 2014, Wurtsbaugh 2014, Jeppesen et al. 2015). In the western United States, nearly all terminal lakes have experienced recent reductions in size and resultant increases in salinity. For example, since the 1800s, the Great Salt Lake has lost about $35 \%$ of its surface area and $48 \%$ of its volume, and its salinity has increased (Wurtsbaugh et al. 2016). Walker Lake in southwestern Nevada has dropped 150 feet in the past century and salinity has increased 10-fold, which has had a severe effect on its biota (Herbst et al. 2014). Similarly, the Salton Sea is experiencing a reduction in size and increased salinity, with adverse effects seen and predicted for its ecosystem if inflows do not increase (Case et al. 2013, Cohen 2014). Similar issues are affecting Mono and Pyramid Lakes.

In 2014, Lake Abert, located in south central Oregon, shrank to about $5 \%$ of its maximum size, and its salinity increased from a longterm average of $75 \mathrm{~g} \cdot \mathrm{L}^{-1}$ to $250 \mathrm{~g} \cdot \mathrm{L}^{-1}$. This resulted in a major ecosystem shift from one dominated at higher trophic levels by invertebrates and waterbirds to one composed primarily of hypersaline-adapted microbes.

\footnotetext{
${ }^{1}$ Klamath Falls, OR. E-mail: rlarson@ccountry.net

${ }^{2}$ MaxDepth Aquatics, Inc., Bend, OR

${ }^{3}$ Oregon Desert Brine Shrimp, Portland, OR

${ }^{4}$ College of Arts and Sciences, University of Baltimore, Baltimore, MD.

5Department of Microbiology and Immunology, University of Maryland School of Medicine, Baltimore, MD.

${ }^{6}$ East Cascades Audubon Society, Bend, OR.

${ }^{7}$ Institute of Marine and Environmental Technology, University System of Maryland, Baltimore, MD.
} 
The last time the lake was in this state was nearly a century ago in the 1930s during the Dust Bowl, which was determined to be a once-in-500-year drought in central Oregon (Pohl et al. 2002).

Salt lakes in the Great Basin and elsewhere are known to have low species richness compared to freshwater lakes, and diversity often declines with increasing salinity, especially above $150 \mathrm{~g} \cdot \mathrm{L}^{-1}$ (Hammer 1986, Williams et al. 1990, Herbst 2001); however, their high invertebrate production makes them key foraging and staging habitats for migratory waterbirds (Jehl 1988, 1994, 1999, Oring et al. 2009, Colwell 2010). At Lake Abert, brine shrimp (Artemia franciscana) numbers have been estimated at $3 \times 10^{11}$ individuals and their biomass at $7 \times 10^{6} \mathrm{~kg}$ (Conte and Conte 1988). Furthermore, adult alkali flies (Ephydra hians) at Lake Abert can be so numerous they can densely cover large areas along the shore and over the lake surface (Herbst 1988, 1994). The abundance of these invertebrates has made the lake a crucial foraging and staging habitat for migratory waterbirds, especially Wilson's Phalarope (Phalaropus tricolor), which can reach several hundred thousand in number during the postbreeding, midsummer migration. For example, in late July 2013, it was estimated that one-fifth of the global Wilson's Phalarope population had staged at the lake (C. Hinkle, data from ebird.org, 30 July 2013). Lake Abert, along with the Great Salt Lake and Mono Lake, provides the necessary trophic conditions for Wilson's Phalarope to double their weight in less than a month before making the $8000-\mathrm{km}$ migration to wintering areas in South America (Jehl 1988, Colwell and Jehl 1994, Lesterhuis and Clay 2010).

The foundation of the food chain in alkaline salt lakes and solar lakes with low to moderate salinities $\left(60-100 \mathrm{~g} \cdot \mathrm{L}^{-1}\right)$ is the diverse and highly productive microbial communities that include photosynthetic unicellular and filamentous cyanobacteria, as well as purple and green sulfur and nonsulfur bacteria. These communities support dense populations of algae, as well as some protozoa and fungi, which provide food for brine shrimp and alkali flies (DasSarma and DasSarma 2012). With increasing salinity $\left(140-250 \mathrm{~g} \cdot \mathrm{L}^{-1}\right)$, most of the primary producers (the cyanobacteria and eukaryotic algae) disappear (Hammer 1986). As the extreme saline conditions approach
$\mathrm{NaCl}$ saturation $\left(>250 \mathrm{~g} \cdot \mathrm{L}^{-1}\right)$, microbial communities become primarily composed of redcolored halophilic Archaea, with most other microbial activity ceasing (Javor 1989, Caumette 1993, Ochsenreiter et al. 2002, Mesbah et al. 2007, DasSarma and DasSarma 2012).

To understand the causes of the 2014 neardesiccation event and its effects on the Lake Abert ecosystem, we examined a variety of physical and biological data. Although data were limited, the dramatic decline in the size of the lake, its extreme salinity increase, and the marked changes in the biota of this relatively simple system make a convincing argument that biotic and physical changes were related.

\section{Study Area}

Lake Abert is located in south central Oregon and is part of the Great Basin (Fig. 1). It is the largest hypersaline lake in the Pacific Northwest and at full pool is the 6th largest lake in Oregon. At $25 \mathrm{~km}$ long and $10 \mathrm{~km}$ wide, Lake Abert covers approximately $170 \mathrm{~km}^{2}$ but averages only approximately $1.5 \mathrm{~m}$ deep (Fig. 2).

Salinities in the lake normally range from $20 \mathrm{~g} \cdot \mathrm{L}^{-1}$ to $80 \mathrm{~g} \cdot \mathrm{L}^{-1}$ and have averaged 75 $\mathrm{g} \cdot \mathrm{L}^{-1}$ since 1973 . The most common ions are $\mathrm{Na}^{+}, \mathrm{CO}_{3}^{-2}$ and $\mathrm{Cl}^{-}$; and the $\mathrm{pH}$ is normally above 9 (Phillips and VanDenburgh 1971, VanDenburgh 1975). The lake was part of the much larger Paleolake Chewaucan that began desiccating near the end of the Pleistocene epoch, approximately 12,000 years ago (Allison 1982, Licciardi 2001).

The region has a cold, semiarid steppe climate, termed BSk in the Köppen climate classification. Average annual temperature is $8.4{ }^{\circ} \mathrm{C}$, and average maximum and minimum temperatures are $17.2^{\circ} \mathrm{C}$ and $-0.3^{\circ} \mathrm{C}$, respectively, based on data from nearby Alkali Lake, Oregon, located $45 \mathrm{~km}$ northeast of Lake Abert (Western Regional Climate Center, www.wrcc.dri.edu). Average annual precipitation is $22 \mathrm{~cm}$; and over the past 40 years, precipitation has varied between $10 \mathrm{~cm}$ and $38 \mathrm{~cm}$. We estimate that average annual freshwater evaporation amounts are approximately $1 \mathrm{~m}$.

The lower Chewaucan River, the main source of water to Lake Abert, was channelized early in the 20th century to reduce flooding at the small town of Paisley (OWRD 1989; Fig. 1). Previously the river lacked a definite channel, and the river flowed through a large marsh as it entered the low-gradient portion 


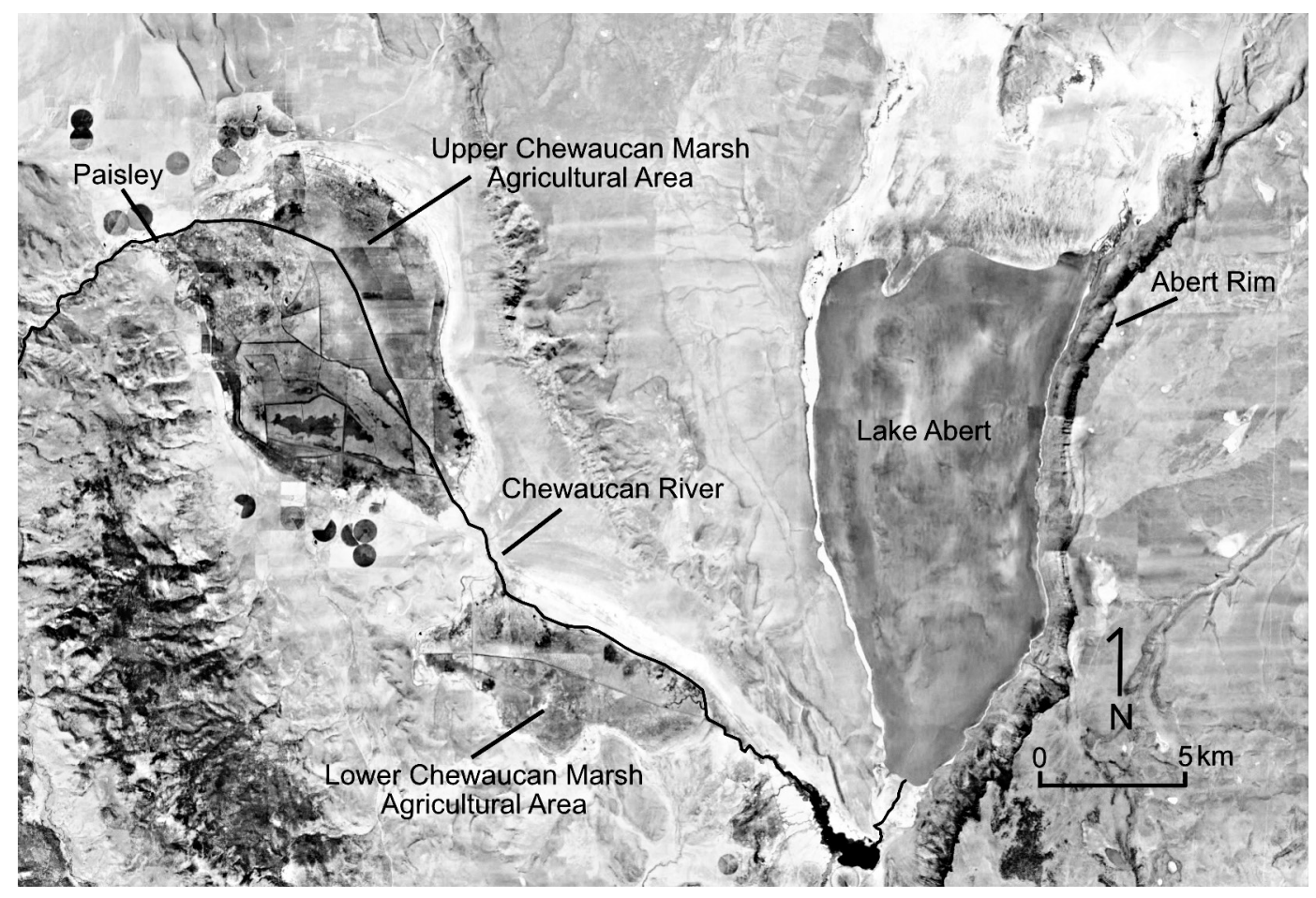

Fig. 1. Lake Abert area map (base image (c) 2016 Google).

of the watershed near Paisley. Agricultural water diversions from the river primarily occur between Paisley and Lake Abert, and together their area is approximately $200 \mathrm{~km}^{2}$ (USDA 2006). The Oregon Water Resources Department (OWRD) stated that if all water rights in the Chewaucan Basin, which total $72 \times 10^{6} \mathrm{~m}^{3}$, were fully used, an annual diversion from the river of over $247 \times 10^{6} \mathrm{~m}^{3}$ would be required; however, the annual average total flow of the river is only $140 \times 10^{6} \mathrm{~m}^{3}$ (OWRD 1989). Additionally, groundwater totaling $15 \times 10^{6} \mathrm{~m}^{3}$ annually is pumped from wells to irrigate approximately $20 \mathrm{~km}^{2}$ (USDA 2006). Additional evaporation and irrigation withdrawals occur at River's End Reservoir $\left(2.6 \mathrm{~km}^{2}\right)$, constructed in 1994 at the terminus of the river.

Two named ephemeral creeks-Poison and Juniper-discharge into Lake Abert. Poison Creek has the most sustained flows, but by July low summer flows become hyporheic about $0.5 \mathrm{~km}$ east of the lake. There are also numerous small springs and seeps located around the lake. These were particularly noticeable during recent low lake levels. The flow of many of these springs is too small to reach the lake when it is low; but some larger springs, especially those along the northeast side of the lake, contribute water to the lake. The largest of these is a $3-\mathrm{km}$-long complex located between $42^{\circ} 42^{\prime} 20^{\prime \prime} \mathrm{N}$ and $42^{\circ} 40^{\prime} 50^{\prime \prime} \mathrm{N}$. The significance of this spring complex was evident in Landsat scenes from 2014 and 2015, when an elongated pool northeast of the main pool at the lake covered an area of $3-6 \mathrm{~km}^{2}$ and composed up to $50 \%$ of the total inundated area associated with the lake. In September 2015 , we measured flows totaling $0.3 \mathrm{~m}^{3} \cdot \mathrm{s}^{-1}$ from the large spring complex. Based on those measurements and evidence of additional springs and seasonal streams that empty into the lake, we assumed that the locally derived annual inflows average approximately $0.6 \mathrm{~m}^{3} \cdot \mathrm{s}^{-1}$.

Ungauged flows also result from streams located between the Paisley gauge and the lake, most of which are small and ephemeral. The largest are Crooked, Moss, and Willow Creeks. Of these, Crooked Creek is the largest. Crooked Creek is affected by upstream diversions, so it is likely that little flow reaches the 


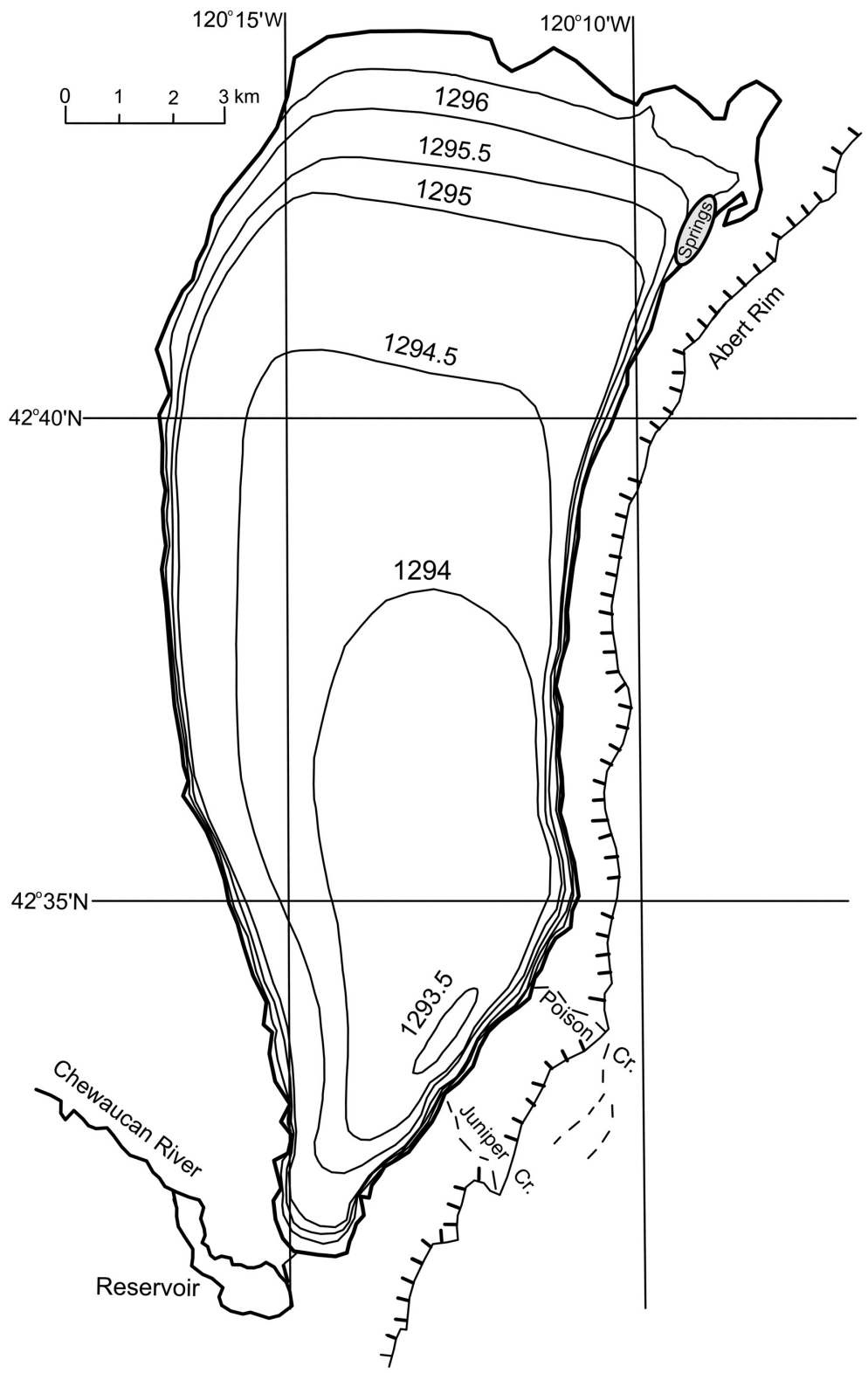

Fig. 2. Lake Abert bathymetry, with depths shown in meters (after Phillips and VanDenburgh 1971). River's End Reservoir, shown near the inlet, was constructed in 1994.

river during the June-September irrigation season, except in wet years.

\section{Methods}

\section{Biological Data}

For the assessment of microbial communities, sediment samples were collected at 7 sites along the eastern shore of Lake Abert during the high-salinity event in October 2014. Samples were shipped on ice to the University of Maryland School of Medicine in Baltimore, Maryland. Genomic DNA was extracted using the PowerLyzer ${ }^{\circledR}$ PowerSoil ${ }^{\circledR}$ DNA isolation kit per manufacturer's recommendation (MO BIO Laboratories, Inc., Carlsbad, CA), and DNA samples were pooled at equal nucleic acid concentration. 16S metagenomic sequencing 
was performed by the Bioanalytical Services Laboratory at the Institute for Marine and Environmental Technology, Baltimore, Maryland, on an Illumina MiSeq platform per manufacturer's recommendation (Illumina, Inc., San Diego, CA). The protocol used the primer pair Bakt_341F and Bakt_805R (Herlemann et al. 2011). Sequences were analyzed with the open source bioinformatics packages QIIME (Caporaso et al. 2010) and ea-utils 1.1.2-621 (Aronesty 2013) and were queried against the Greengenes 16S rRNA database (released August 2013; http://greengenes.lbl.gov/cgi-bin/ nph-index.cgi; DeSantis et al. 2006).

Artemia has been harvested from the lake every year between 1980 and 2013 (MaySeptember) by the Oregon Desert Brine Shrimp Company, except in 1996 when there was no need to harvest because adequate shrimp remained in storage from the previous year. Artemia was harvested using a small raft equipped with a pair of plankton nets and a small outboard motor. Catch per unit effort (CPUE) was calculated based on wet weight of harvested Artemia per hour of sampling from 1986 to 2013, when net size remained constant. Other aquatic macroinvertebrates were collected using small hand nets and a $1.5-\mathrm{mm}$ mesh sieve. Waterbird census data were produced by volunteers from the East Cascades Audubon Society, and other data sets were obtained from unpublished sources and the ebird.org web site (www.ebird.org/ content/ebird/).

\section{Physical Data}

To assess the physical changes affecting the lake, we quantified key hydrological and climatological parameters, including (1) surfacearea changes measured from Landsat satellite scenes; (2) precipitation and class-A pan evaporation measured at nearby locations; (3) local inflow from seeps, springs, and ephemeral streams measured at one location; and (4) Chewaucan River flow measured upstream of most of the agricultural diversions.

Because regular and frequent water-level measurements of the lake are unavailable, we documented temporal changes in lake surface area from satellite images, also called "scenes," made between 1973 and 2015. A total of 470 "natural color" scenes taken by Landsat satellites fitted with 4 different sensors were downloaded directly from the U.S. Geological
Survey LandsatLook Viewer web site (http:// landsatlook.usgs.gov/viewer.html). Area measurements were made by digitizing the outline of the inundated perimeter using Image J, a free public-domain image analysis software (www.imagej.nih.gov/ij/).

At low lake levels, shallow water approximately $10 \mathrm{~cm}$ deep covers large areas of the lake bed and there are also extensive areas of wet mud, both of which make it challenging to determine from the satellite images where the inundated perimeter was located. Although these factors contribute to uncertainty in estimates of lake area, they likely have little effect on the hydrologic modeling results because errors in volume would be small relative to those from the large temporal changes involved.

Data on daily Chewaucan River flow was measured at station \#10384000, located near Paisley, Oregon, 50-km upstream from Lake Abert, and were obtained from the OWRD web site (http://apps.wrd.state.or.us/apps/sw/ hydro_near_real_time/display_hydro_graph .aspx? station_nbr=10384000). Because this station is the only flow-measurement gauge on the river, no data were available on inflows to the lake. Hydrologic data here are presented as water years (WYs), which begin on 1 October and end the following year on 30 September and are named for the year in which they end.

Evaporation losses from the lake were estimated from monthly data measured using a class-A evaporation pan and corrected for effects of open-water conditions and salinity. Measurements were made near Summer Lake, Oregon, located $50 \mathrm{~km}$ northwest of Lake Abert, and were obtained from the Western Regional Climate Center in Reno, Nevada, and from the Summer Lake Wildlife Area (M. St. Louis, personal communication, 2015). Evaporation data were for April-October, so totals for the rest of the year were based on data in Risley and Gannett (2006) measured in the Upper Klamath Basin, $100 \mathrm{~km}$ to the west. Open-water evaporation amounts were estimated from the pan measurements using a 0.7 correction factor (Jensen 2010). Because evaporation rates decline with increasing salinity (by $1 \%$ at $40 \mathrm{~g} \cdot \mathrm{L}^{-1}$ and $20 \%$ at $250 \mathrm{~g} \cdot \mathrm{L}^{-1}$ ), corrections were made based on measurements made by Turk (1970) using a third-order polynomial equation: 
TABLE 1. Information used to estimate salinity from surface-area measurements.

\begin{tabular}{|c|c|c|c|c|c|}
\hline$Y$ variable & $X$ variable & Equation & $\mathrm{R}^{2}$ & $\begin{array}{l}\text { Sample } \\
\text { size }\end{array}$ & Data sources \\
\hline Salinity $\left(\mathrm{g} \cdot \mathrm{L}^{-1}\right)$ & Elevation $(\mathrm{m})$ & $y=2 \mathrm{E}+13 x^{-9.599}$ & 0.91 & 42 & $\begin{array}{l}\text { Phillips and VanDenburgh (1971), } \\
\text { D. Herbst (personal communica- } \\
\text { tion 2015), and unpublished data }\end{array}$ \\
\hline Elevation (m) & Area $\left(\mathrm{km}^{2}\right)$ & $\begin{aligned} y= & 3 \mathrm{E}-06 x^{3}-0.0006 x^{2} \\
& +0.0409 x+1293.6\end{aligned}$ & 0.98 & 45 & Unpublished data \\
\hline Salinity $\left(\mathrm{g} \cdot \mathrm{L}^{-1}\right)$ & Area $\left(\mathrm{km}^{2}\right)$ & $\begin{aligned} y= & -0.0024 x^{2}-1.398 x \\
& +310.46\end{aligned}$ & 0.99 & 42 & All of the above sources \\
\hline
\end{tabular}

$y=1 \mathrm{E}-06 x^{3}-0.0001 x^{2}+0.0363 x-0.2828$,

where $y=$ percent reduction in evaporation rates and $x=$ salinity $\left(\mathrm{g} \cdot \mathrm{L}^{-1} ; \mathrm{R}^{2}=0.99, n=14\right)$.

Annual precipitation amounts, based on measurements made at Alkali Lake, Oregon, were downloaded from the Weather Warehouse (http://weather-warehouse.com). Of the 2 nearest weather stations, Alkali Lake and Paisley, we selected the former based on a similarity of vegetation with that around Lake Abert. Both areas of Lake Abert have primarily a treeless shrubsteppe vegetation comprising grasses and drought-adapted shrubs such as greasewood (Sarcobatus vermiculatus), shadscale (Atriplex confertifolia), and sagebrush (Artemisia spp.).

Salinity was measured from water samples using either a hydrometer or refractometer, and water samples were collected at the same time lake levels were measured from a staff gauge located along the eastern shore. We used these data as well as surface-area measurements made from Landsat scenes to access temporal variations in salinity by developing 3 equations (Table 1): one relating lake elevation and salinity, one relating lake elevation and area, and one relating salinity and surface area.

\section{RESUlTS}

\section{Biological Observations}

Prokaryotic COmmunity.-To assess the prokaryotic community of Lake Abert, 16S rRNA metagenomic analysis was performed. A total of 192,876 sequences were obtained, representing 7378 unique operational taxonomic units (OTUs). Analysis of different diversity indices and measurements (Chaol, Shannon-Weaver, equitability) suggests that the Lake Abert microbial community is complex and diverse. The Chaol index was 7378 , the Shannon-Weaver index was 9.4, and the equitability was 0.7 . A majority of reported sequences were identified as Bacteria (95.4\%), while $1.0 \%$ belonged to Archaea and 3.4\% were unclassified (Fig. 3).

At the phylum level, $96.5 \%$ of the sequences could be assigned to 54 phyla. Among those, 51 bacterial phyla were identified. Proteobacteria $(26.7 \%$ of total reads), Bacteroidetes (21.1\% of total reads), Firmicutes (16.1\% of total reads), and Cyanobacteria (14.6\% of total reads) contributed to $79 \%$ of the microbial community (Fig. 3A). Among the Proteobacteria, $\gamma$-proteobacteria (11.1\%), dominated by the genus Thioalkalivibrio (2.4\%), were most abundant, followed by $\alpha$-proteobacteria (10.7\%), dominated by the family of Rhodobacteraceae. Abundant genera within the Bacteroidetes included Flavobacterium and Salinibacter $(0.5 \%$ and $0.3 \%$, respectively). Within the Firmicutes, Clostridia and Bacilli were prominent $(14.0 \%$ and $2.0 \%$, respectively). On the genus level, the Clostridia genus Tindallia was prominent (1.4\%). Other genera included Alkaliphilus, Halanaerobacter, Halanaerobium, and Natranaerobius, representing alkaliphilic and halophilic bacteria. Genera within Bacilli included Planomicrobium, Bacillus, and Alkalibacterium. Among the Cyanobacteria, members of the genus Cyanothece that includes the halophilic variety were present in Lake Albert $(0.2 \%$ of total reads).

Sequences corresponding to many bacterial groups that are involved in biogeochemical cycles were found in Lake Abert. These included Cyanobacteria and phototrophic purple sulfur bacteria of the genus Halorhodospira, which are involved in carbon fixation; alkaliphilic sulfur-reducing bacteria of the genera Desulfonatronum, Desulfonatronospira, and Desulfonatronovibrio; sulfur-oxidizing bacteria 
A

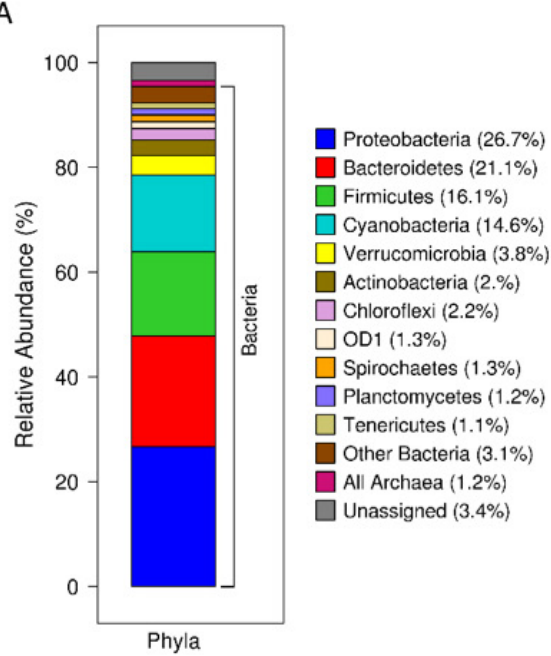

B

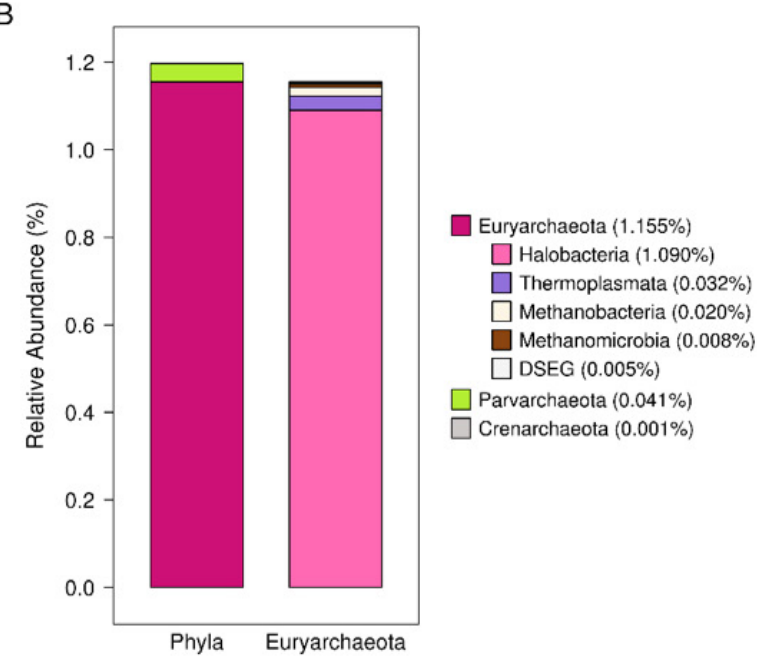

Fig. 3. Distribution of $16 \mathrm{~S}$ rRNA sequences corresponding to the phylogenetic groups observed in Lake Abert: A, Relative abundance of prokaryotic phyla. The group "Other Bacteria" includes bacterial phyla with a relative abundance below $1.1 \%$; B, Relative abundance of archaeal phyla and classes within the Euryarchaeota.

such as Thioalkalivibrio; and bacteria belonging to the genus Halomonas, which are involved in the nitrogen cycle.

The archaeal community was dominated by sequences from members of Euryarchaeota (1.2\% of total reads). Within Euryarchaeota, the class Halobacteria (Haloarchaea), which consists of extremely halophilic species, constituted $94 \%$ of the archaeal community (Fig. $3 \mathrm{~B})$. At the genus level, Halorhabdus and Halorubrum were most prevalent $(0.1 \%$ and $0.1 \%$ of all reads, respectively), followed by Natronorubrum and Natronococcus $(0.1 \%$ and $0.04 \%$ of all reads, respectively).

Algae and invertebrates.-To document temporal changes in the biota, we focused on the dominant taxa: a filamentous green alga (Ctenocladus circinnatus), brine shrimp (Artemia franciscana), alkali flies (Ephydra hians), and waterbirds. Up until 2013, C. circinnatus was seasonally abundant in the lake, both as mats attached to rocks and as marble-sized balls sitting on the mud, in the water column, or at the water surface. By late summer, C. circinnatus formed extensive dense masses concentrated along the shore; and in some years, floating masses of $C$. circinnatus were sometimes so dense that they interfered with shrimp harvesting. However, no such concentrations were observed in 2014 or 2015.
Artemia was sufficiently abundant that it supported a commercial fishery up until 2013. Average annual CPUE from 1986 to 2014 ranged from approximately $50 \mathrm{~kg} \cdot \mathrm{h}^{-1}$ to 100 $\mathrm{kg} \cdot \mathrm{h}^{-1}$; catches peaked in July and August. Annual catches were relativity high even in recent years, such as in 2010 and 2013 when salinity was increasing.

The first recent indication that ecological changes were occurring in the lake was in August 2010, when Artemia individuals turned red, were lethargic, and accumulated in nearshore windrows where they died. We attributed the red coloration to the production of hemoglobin, which apparently occurred or increased as a result of hypersaline-induced hypoxia. The salinity at that time was approximately $150 \mathrm{~g} \cdot \mathrm{L}^{-1}$. Inflows in 2011 diluted the lake down to approximately $80 \mathrm{~g} \cdot \mathrm{L}^{-1}$, and in 2012 salinity never exceeded $140 \mathrm{~g} \cdot \mathrm{L}^{-1}$. In spring 2013, the south end of the lake was sufficiently dilute $\left(<130 \mathrm{~g} \cdot \mathrm{L}^{-1}\right)$; but by July, salinity was up to $150 \mathrm{~g} \cdot \mathrm{L}^{-1}$ and in August it reached $170 \mathrm{~g} \cdot \mathrm{L}^{-1}$, at which time the shrimp died. By September 2013, the lake was so saline (over $180 \mathrm{~g} \cdot \mathrm{L}^{-1}$ ) that layers of trona salts up to approximately $10 \mathrm{~cm}$ thick formed along the shoreline and on the lake bed.

In 2014, the lowest salinities were estimated to have been approximately $180 \mathrm{~g} \cdot \mathrm{L}^{-1}$ in April; and as a result, no Artemia were seen. 


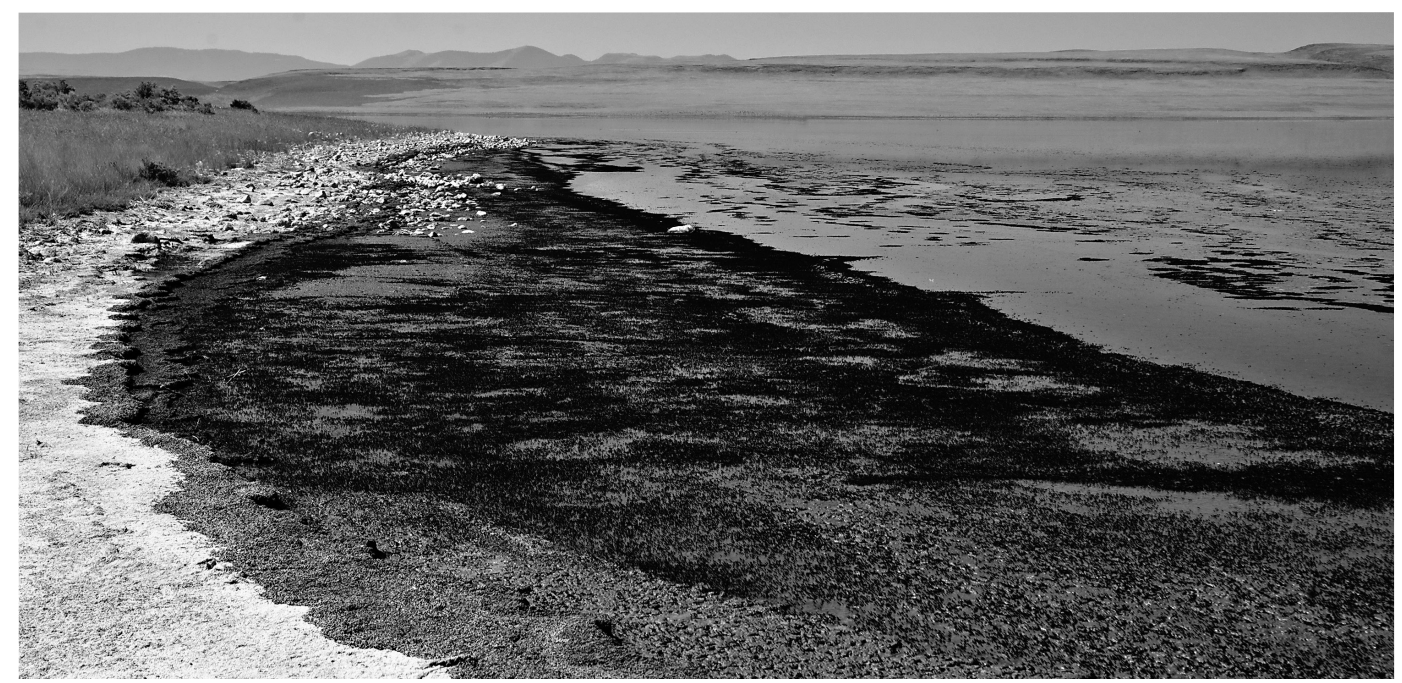

Fig. 4. Adult alkali flies partially covering an exposed mudflat approximately $100 \mathrm{~m}$ long and floating in masses on the water surface of Lake Abert (2 September 2011). Light-colored empty pupal cases piled up on the beach are visible on the far left of the photo.

By July 2014, the salinity was estimated to be approximately $250 \mathrm{~g} \cdot \mathrm{L}^{-1}$ and the lake turned blood red owing to the presence of hypersalineadapted microbes, probably Archaea species. In 2015, inflows to the lake diluted the south end sufficiently that some brine shrimp hatched, but they died in June when salinities reached $200 \mathrm{~g} \cdot \mathrm{L}^{-1}$. However, in September 2015 , we found low numbers of brine shrimp in the spring-influenced pool near the northeast shore where salinities were between $17 \mathrm{~g} \cdot \mathrm{L}^{-1}$ and $59 \mathrm{~g} \cdot \mathrm{L}^{-1}$.

Besides Artemia, the other ecologically important invertebrate in the lake under moderate salinities is the alkali fly (Ephydra hians), although other saline-tolerant flies have also been observed when the lake was more dilute (Boula 1986, Herbst 1988). Until 2012, adult alkali fly populations at the lake were relatively high, and the flies were conspicuous along most of the eastern shoreline. By late summer, they were often so numerous, numbering thousands per square meter, that they appeared at a distance as black patches of tar covering many square meters and could also be seen floating on the water surface far out on the lake (Fig. 4).

By 2012 , adult alkali flies were only seen near freshwater seeps; and in 2014, adult flies were extremely scarce and consisted mostly of scattered individuals. The only concentrations of adult flies seen in 2015 were several small patches $\left(<0.5 \mathrm{~m}^{2}\right)$ adjacent to the low-salinity pool created by springs along the northeast side of the lake bed. However, near-surface sediment samples taken from the pool contained alkali fly larvae and pupae. The salinity in the pool ranged from $17 \mathrm{~g} \cdot \mathrm{L}^{-1}$ to $59 \mathrm{~g} \cdot \mathrm{L}^{-1}$ and was lowest at the north end closer to the spring discharge. Gammaridean amphipods and corixid insects were present in and near the spring heads where the salinity was $4 \mathrm{~g} \cdot \mathrm{L}^{-1}$.

During the recent period of low lake level, moist sandy-mud substrates around the perimeter of the lake were dotted with the castings of Bledius sp., a burrowing rove beetle (Staphylinidae) known to inhabit the littoral zones of saline lakes (Garcia and Niell 1991, Gerdes et al. 2008). In some areas, burrows reached estimated densities of over $100 \cdot \mathrm{m}^{-2}$. In October 2014 , adult Bledius sp. beetles were seen swarming aerially at the south end of the lake.

WATERBIRDS.-Waterbirds can be both numerous and diverse at Lake Abert, with $>80$ species and hundreds of thousands of birds reported. The most plentiful waterbird species are listed in Table 2, along with maximum numbers reported between 2011 and 2015.

All of the most numerous waterbird species at the lake showed evidence of lower population sizes in 2014 and 2015 compared to 
TABLE 2. Peak counts of the most numerous waterbirds occurring at Lake Abert between 2011 and 2015. Data were from the East Cascades Audubon Society and the ebird.org web site accessed 7 October 2015.

\begin{tabular}{|c|c|c|c|c|c|c|}
\hline Waterbird & Species & 2011 & 2012 & 2013 & 2014 & 2015 \\
\hline American Avocet & Recurvirostra americana & 14,358 & 16,167 & 5475 & 2660 & 78,542 \\
\hline Black-necked Stilt & Himantopus mexicanus & 2000 & 5082 & 375 & 760 & 771 \\
\hline Eared Grebe & Podiceps nigricollis & 11,008 & 40,750 & 21,632 & 0 & 845 \\
\hline Gulls & Larus spp. & 12,290 & 10,261 & 2834 & 215 & 1230 \\
\hline Phalaropes & Phalaropus spp. & 67,071 & 214,000 & 230,000 & 20,985 & 12,845 \\
\hline Northern Shovelers & Anas clypeata & 21,648 & 22,825 & 543 & 2237 & 440 \\
\hline
\end{tabular}

TABLE 3. Comparison of lowest annual Chewaucan River flows measured at Paisley, WY 1925-2015. Note, an exceedance of $99 \%$ means that $99 \%$ of flows were higher during the period of record.

\begin{tabular}{lccc}
\hline $\begin{array}{l}\text { Lowest number } \\
\text { of consecutive } \\
\text { years }\end{array}$ & $\begin{array}{c}\text { Water } \\
\text { years }\end{array}$ & $\begin{array}{c}\text { Mean } \\
\text { annual flow } \\
\left(\mathrm{m}^{3} \cdot \mathrm{s}^{-1}\right)\end{array}$ & $\begin{array}{c}\text { Mean } \\
\text { exceedance } \\
(\%)\end{array}$ \\
\hline 1 & 1931 & 0.98 & 99 \\
2 & $1991-1992$ & 1.52 & 94 \\
3 & $1929-1931$ & 1.65 & 91 \\
4 & $1929-1932$ & 1.96 & 86 \\
5 & $1930-1934$ & 1.97 & 84 \\
6 & $1929-1934$ & 1.93 & 84 \\
7 & $1929-1935$ & 2.08 & 82 \\
8 & $1928-1935$ & 2.28 & 77 \\
9 & $1928-1936$ & 2.45 & 74 \\
10 & $1928-1937$ & 2.46 & 74 \\
\hline
\end{tabular}

2011-2013, especially phalaropes and Eared Grebes (Table 3). There was also evidence of some species spending a shorter time at the lake in 2014 and 2015 compared to 2011-2013. For example, in 2011 phalaropes were present through early October, with counts ranging from 8720 to 16,600 in July; 22,989 to 67,071 in August; 600 to 17,690 in September; and 3700 on 2 October 2011 (Fig. 5). Whereas in 2015 , counts were 1965 to 12,845 in July; 50 to 300 in August; and only a few in September.

Although reported numbers were less in 2014 and 2015 compared to 2011-2013, waterbirds were still present. Most of these birds were found midway down the length of the lower-salinity pool near the northeast shore where the salinity was $17 \mathrm{~g} \cdot \mathrm{L}^{-1}$ to $60 \mathrm{~g} \cdot \mathrm{L}^{-1}$. Observations noted above showed that small numbers of Artemia and alkali fly larvae and pupae were present in the pool and thus likely attracted the birds.

The most numerous birds using the lake are Wilson's Phalaropes, which have exceeded 100,000 birds in late-July and early-August single-day counts, based on census data obtained by the East Cascades Audubon Society. Female Wilson's Phalaropes (Phalaropus tricolor) were seen in mid-July, followed by males, then juveniles in late July. Another plentiful phalarope, the Red-necked Phalarope (P. lobatus), arrived in early August. Its numbers were usually $<10,000$. Between 2011 and 2013 when phalaropes were especially plentiful, in late July, Wilson's Phalaropes were scattered over nearly the entire surface of the lake spinning and pecking at prey (Fig. 6). Eared Grebe, another bird that feeds in open water, can also be abundant, with a peak of $>40,000$ observed in September 2012.

\section{Temporal Changes in Chewaucan River Flows}

Mean annual Chewaucan River flow measured at Paisley was variable over the study period, with a number of low flows occurring in the 1970s (especially WY 1977), late 1980s (especially WYs 1987-1988), early 1990s (especially WYs 1990-1992 and WY 1994), WYs 2001 and 2004, and WYs 2013-2015. Peak flows during the study period occurred in the early 1980s (especially WYs 1982-1984), the late 1990s (especially WYs 1995-1999), and WYs 2006 and 2011 (Fig. 7). From WY 2001 to WY 2015, flows were mostly low and showed little variability, except for an outlier in WY 2001, which was very low, and in WYs 2006 and 2011, which were high. The mean and median annual flows during the WYs 1974-2015 were $4.4 \mathrm{~m}^{3} \cdot \mathrm{s}^{-1}$ and $3.6 \mathrm{~m}^{3} \cdot \mathrm{s}^{-1}$, respectively.

Temporal Changes in Lake Surface Area, Evaporation, Precipitation, and Salinity

Lake Abert surface area changed substantially over time, with multiple peaks and troughs evident (Fig. 7). The smaller variations were seasonal, representing springtime maxima and late-summer/early-fall minima, and the longer ones were decadal-scale, climate-driven changes. From 1973 to 2015, the lake attained its greatest surface area; and in the mid-1980s, it was greater than 170 $\mathrm{km}^{2}$. In WY 2000, the lake began shrinking 


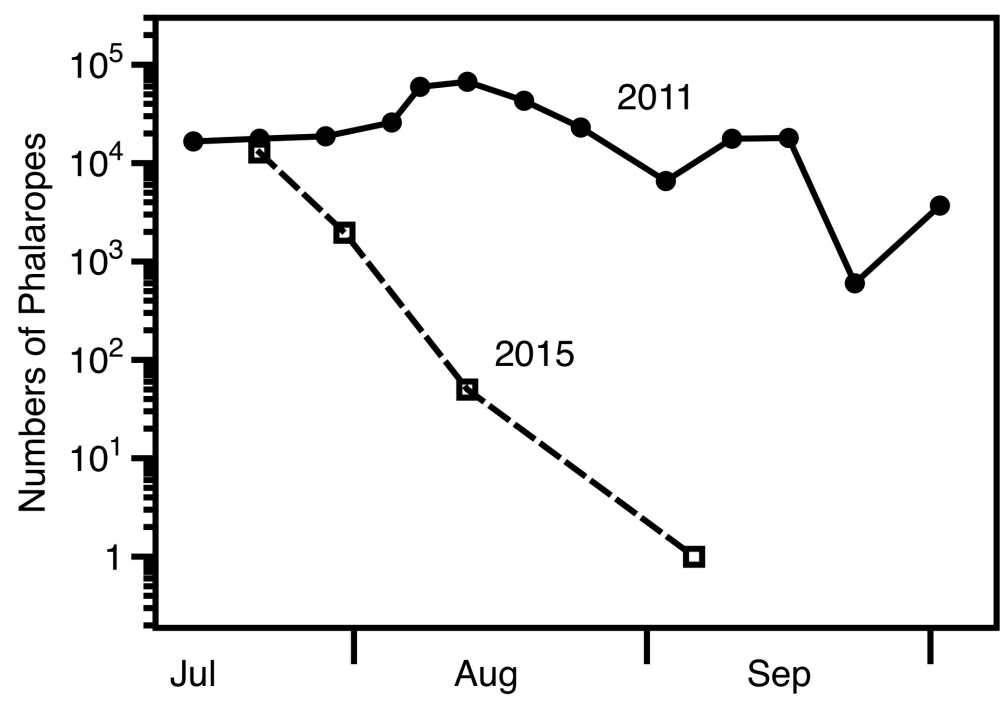

Fig. 5. Total phalarope numbers counted at Lake Abert in 2011 and 2015. Data from East Cascades Audubon Society (S. Dougill, personal communication, 2015).

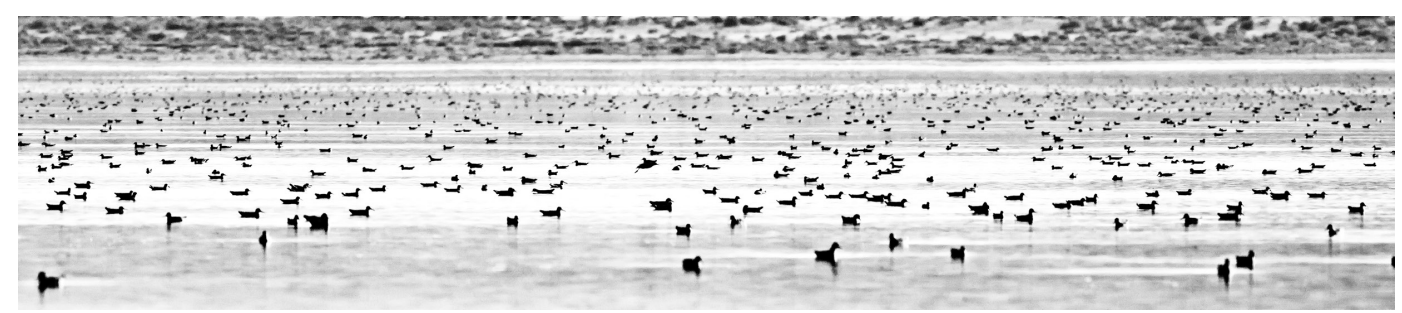

Fig. 6. Phalaropes “spin-feeding” over the surface of Lake Abert on 13 August 2012. An estimated 100,000 phalaropes were present on this day, mostly Wilson's Phalarope.

and reached a minimum surface area of 10 $\mathrm{km}^{2}$ in September 2014.

Class-A pan evaporation amounts measured near Summer Lake, Oregon, May-October from 1962 through 2014 were relatively high during the mid-1960s and 1970s, low in the 1980s, variable in the 1990s, and high but variable from 2000 to 2014 . Since the early 1980 s, there has been a trend of increasing evaporation amounts.

Precipitation amounts measured at Alkali Lake during WYs 1974-1979 varied from $20 \mathrm{~cm}$ to $25 \mathrm{~cm}$ per year. In the $1980 \mathrm{~s}$, there were several years (1980-1983) with relatively high precipitation (26-32 $\mathrm{cm}$ per year), followed by declines to $15 \mathrm{~cm}$ per year in WY 1989. Totals were variable in the 1990s, ranging from $12 \mathrm{~cm}$ to $26 \mathrm{~cm}$ per year, with the lowest amount occurring in WY 1991 (12 cm). Precipitation during WY 2000 was the lowest during the
1973-2014 period $(9.6 \mathrm{~cm})$; thereafter, precipitation increased, peaking in WY 2004 at $39 \mathrm{~cm}$. More recently, precipitation amounts were variable, ranging from $17 \mathrm{~cm}$ to $39 \mathrm{~cm}$ per year, with a peak in WY 2008 of $38 \mathrm{~cm}$.

Estimated salinities for WYs 1974-2014 are shown in Fig. 8. Because salinity is inversely proportional to lake volume, salinity was lowest when the lake volume was greatest and highest when the volume was smallest. Thus, salinity was lowest in the 1980s when the lake was high and increased beginning in WY 2000, reaching $100 \mathrm{~g} \cdot \mathrm{L}^{-1}$ in $2008,150 \mathrm{~g} \cdot \mathrm{L}^{-1}$ in $2010,200 \mathrm{~g} \cdot \mathrm{L}^{-1}$ in 2013 , and $250 \mathrm{~g} \cdot \mathrm{L}^{-1}$ in 2014 . We found that winter and spring inflows from the river at the south end of the lake reduced salinity there, so seasonal salinity is not necessarily uniform throughout the lake. 


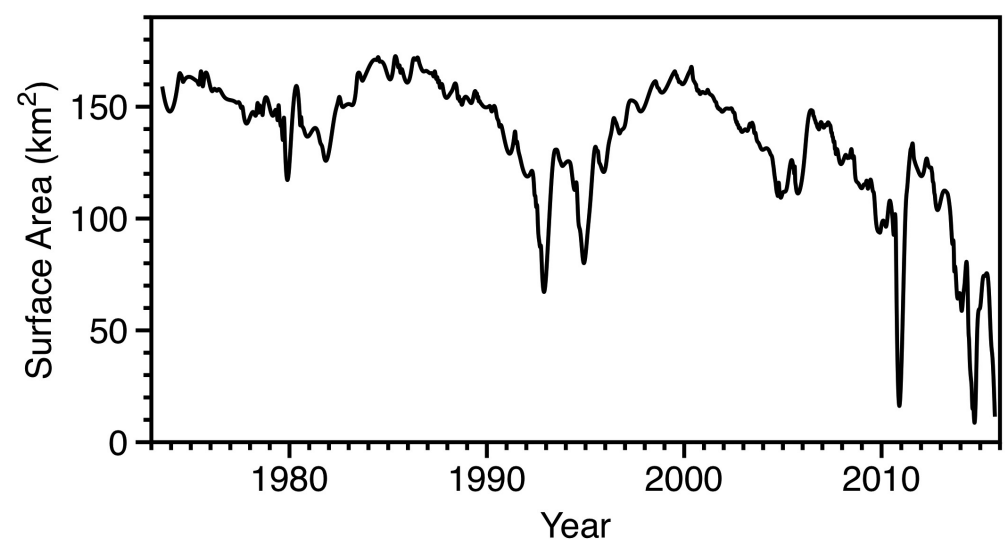

Fig. 7. Temporal variation of Lake Abert surface area, calendar years 1973-2015.

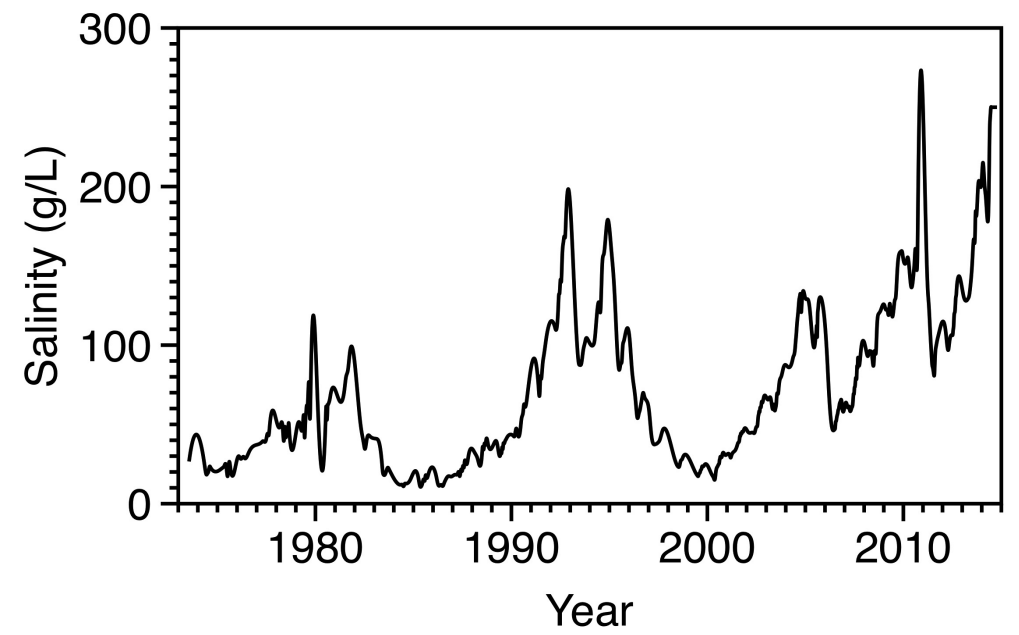

Fig. 8. Temporal variation of Lake Abert salinity, calendar years 1973-2015.

\section{Discussion}

\section{Changes in Hydrology}

Based on the above data and analyses, Lake Abert began a precipitous decline in surface area in WY 2000, decreasing from $165 \mathrm{~km}^{2}$ in July 1999 to $10 \mathrm{~km}^{2}$ by September 2014 . With the above data it is possible to assess the causes of the decline. Because Lake Abert is a terminal lake with no outlet, its water balance is dominated by evaporation and inflows from the Chewaucan River. When the surface area remains in a steady state, evaporation is balanced by the sum of precipitation, plus locally derived inflows and inflows from the Chewaucan River. From WYs 2007 to 2014, the average area of the lake decreased at the fastest rate over the 1973-2015 period, decreasing from $135 \mathrm{~km}^{2}$ to $49 \mathrm{~km}^{2}$; consequently, local inflows plus precipitation and river inflows were inadequate to maintain the lake area, even though total evaporation losses had been reduced both by the lake's smaller surface area and by the effect of higher salinity. Under average conditions during that period, the lake surface area would have reached about $100 \mathrm{~km}^{2}$ and the mean annual rates for evaporation, precipitation, and locally derived inflows would have equaled $2.9 \mathrm{~m}^{3} \cdot \mathrm{s}^{-1}, 0.8 \mathrm{~m}^{3} \cdot \mathrm{s}^{-1}$, and $0.6 \mathrm{~m}^{3} \cdot \mathrm{s}^{-1}$, respectively. Subtracting the value of annual precipitation and local inflows from annual evaporation results in a deficit 
of $1.5 \mathrm{~m}^{3} \cdot \mathrm{s}^{-1}$ that would need to be met by river inflows to achieve an area steady state. During WYs 2007-2014, mean annual river flow measured at Paisley averaged $3.6 \mathrm{~m}^{3} \cdot \mathrm{s}^{-1}$; thus on average an estimated $42 \%(1.5 / 3.6)$ of the flow measured at Paisley reached the lake. In contrast, Phillips and VanDenburgh (1971) and Keister (1992) estimated that over the 1926-1963 and 1926-1990 periods, 50\% and $70 \%$, respectively, of the annual river flow measured at Paisley reached the lake. Thus, recent water diversions have increased relative to river flow. Based on the relatively low river flows occurring between WYs 2007 and 2014 , the use of flood irrigation at a time when evaporation was increasing, and the overappropriated water rights in the Chewaucan Basin, it is not surprising that a greater proportion of the river flow was used to meet agricultural withdrawals.

The results of this study agree with those of Moore (2016) who concluded that (1) water withdrawals substantially contributed to the recent desiccation event, (2) without water withdrawals the lake would have maintained a higher volume and lower salinity, and (3) such conditions would mostly have been within the salinity optimal range for brine shrimp and alkali flies, which is $<150 \mathrm{~g} \cdot \mathrm{L}^{-1}$.

Low flows in the Chewaucan River were a contributing factor to the recent near desiccation of Lake Abert, but compared to historical flows they are not drastic. Table 3 presents a comparison of the lowest annual flows (WYs 1925-2015) based on consecutive years. During the Dust Bowl in the 1920s and 1930s, flows were exceptionally low, with annual means ranging from $1 \mathrm{~m}^{3} \cdot \mathrm{s}^{-1}$ to $2.5 \mathrm{~m}^{3} \cdot \mathrm{s}^{-1}$; and with the exception of 1991 and 1992, these WYs set records for lowest 1-10 consecutive years. In contrast, WYs 2001-2015, with a mean annual flow of $3.6 \mathrm{~m}^{3} \cdot \mathrm{s}^{-1}$ and an exceedance of $52 \%$ (i.e., $52 \%$ of flows were higher), were not represented in the lowest 1-30 consecutive years. Thus, although recent flows were low, on average they are not remarkable when viewed over the 93-year period of record; and in fact, the mean flow of $3.6 \mathrm{~m}^{3} \cdot \mathrm{s}^{-1}$ during WYs $2001-2015$ is equal to the median flow over the longer WY 1974 2015 period. Nevertheless, it should be noted that drought conditions in central Oregon during the 1930s are considered the most sustained in the last 500 years, based on a climate reconstruction from analyses of tree rings (Pohl et al. 2002).

Besides agricultural diversions from the river, other factors may have contributed to reduced inflows into the lake. Since about 1990, groundwater usage has increased in the basin, as evidenced by the proliferation of center-pivot irrigation for alfalfa production, which now occupies approximately $67 \mathrm{~km}^{2}$. This shift from production of grass hay to alfalfa, which is a water-intensive crop, has likely adversely affected the aquifer, especially since 2001 as a result of the recent drought and higher evaporation rates. In fact, there has been a steady decline in the water table, based on data reported by OWRD for Lake County wells \#1633 and \#1719. Additionally, upstream habitat enhancement projects for waterfowl that impounded water, such as the construction of the River's End Reservoir in the 1990s, likely reduced inflows to the lake.

\section{Assessment of the Microbial Community}

With more than 7300 unique OTUs and an equitability of 0.73 , the prokaryotic microbial community of Lake Abert is diverse. The composition of the prokaryotic microbial community is similar to microbial communities reported for other moderate to hypersaline alkaline lakes (Caumette 1993, Humayoun et al. 2003, Mesbah et al. 2007, Dimitriu et al. 2008, Pagaling et al. 2009, Asao et al. 2011, Lanzén et al. 2013, Dadheech et al. 2013). Although the presence of DNA sequences does not make it possible to draw conclusions on the level of productivity and activity of the members of microbial communities, it is likely to be an indication of their productivity potential. Therefore, based on the presence of diverse Bacteria and Archaea known to be involved in biogeochemical cycles (e.g., haloalkaliphilic or halophilic members of oxygenic and anoxygenic phototrophs, sulfur oxidizing and reducing bacteria, bacteria involved in the nitrogen cycle, as well as methanogens and methanotrophs), Lake Abert appears to be highly productive. When salinity levels rise above $250 \mathrm{~g} \cdot \mathrm{L}^{-1}$, reaching levels similar to hypersaline solar salterns, the diversity of microorganisms generally decreases, and extremely halophilic species, such as the halophilic archaea, are favored (Javor 1989, DasSarma and DasSarma 2012). Our finding of a substantial number of halophilic archaeal 
sequences in Lake Abert during the historic high-salinity event in 2014 suggests that the microbial community was changing (or had changed) from that characteristic of a moderately saline environment to one of extremely high salinity (Grant et al. 1999, Ochsenreiter et al. 2002, Mesbah et al. 2007, DasSarma and DasSarma 2012, Sorokin et al. 2014). Nevertheless, our metagenomics results may represent considerable diversity from microbial productivity in earlier years. Additional temporal studies over multiple seasons are needed to fully appreciate the relationship between microbial diversity and salinity in Lake Abert.

\section{Salinity-Related Changes in the Macrobiota}

Recent high salinities at Lake Abert have had a dramatic adverse effect on the Lake Abert macroorganisms. The occurrence of hypersaline-adapted microbes in 2014 had not been previously reported from the lake. The filamentous green alga Ctenocladus circinnatus, which was abundant during late summer in the lake up until 2013, was not seen in 2014 or 2015. It is the dominant macroalga in the lake and is known to play an important ecological role in the lake as food for the alkali fly larvae (Herbst 1994, Herbst and Castenholtz 1994); and its decomposition products are likely used by microbes. Benthic algae growth in salt lakes is optimal between salinities of 25 $\mathrm{g} \cdot \mathrm{L}^{-1}$ and $75 \mathrm{~g} \cdot \mathrm{L}^{-1}$ and is severely reduced at $150 \mathrm{~g} \cdot \mathrm{L}^{-1}$ (Herbst 1994). Additionally, Herbst and Bradley (1989) found that overall benthic algal diversity in Lake Abert was reduced in the laboratory at salinities greater than $100 \mathrm{~g} \cdot \mathrm{L}^{-1}$.

Lake Abert has been able to support brine shrimp at least since 1882 (Russell 1884), and there has been an artisanal brine shrimp fishery in the lake since 1980; but that ended in 2013 when there were no brine shrimp. Artemia franciscana is known to survive salinities above $200 \mathrm{~g} \cdot \mathrm{L}^{-1}$ in the laboratory (Castro-Mejia et al. 2011); but at salinities above $150 \mathrm{~g} \cdot \mathrm{L}^{-1}$, in situ productivity and survival substantially decline because of the increasing energy demands of osmoregulation, reduced dissolved oxygen concentrations, and lower food availability (Gajardo and Beardmore 2012).

Artemia harvest CPUE at Lake Abert was largely independent of salinity on an annual basis. However, on a monthly basis, the picture is complicated, because in some years there were no August catches when the salinity would have been greatest. What the Artemia CPUE data show is that the lake remained productive, at least in terms of Artemia standing stock, through July in most years until salinities exceeded $150 \mathrm{~g} \cdot \mathrm{L}^{-1}$. This finding suggests that Artemia adults have a great tolerance for salinity changes. It is unknown how the biomass of Artemia remains relatively stable at times when high salinities are likely adversely affecting primary production, but perhaps Artemia is able to switch from phytoplankton to bacterial plankton as salinity increases. Or perhaps Artemia can use stored glycogen to meet metabolic demands. However, when salinities climbed above $150 \mathrm{~g} \cdot \mathrm{L}^{-1}$, Artemia individuals were unable to meet their metabolic demands and died.

Alkali flies, which as adults were visibly conspicuous in previous years, were nearly absent in 2014 and 2015 when salinities were high. Herbst (1994) determined that alkali fly production in Lake Abert was greatest when salinities were $25 \mathrm{~g} \cdot \mathrm{L}^{-1}$ to $100 \mathrm{~g} \cdot \mathrm{L}^{-1}$. In addition to lower productivity of alkali flies and benthic algae at high salinities, low lake levels reduced or eliminated the availability of rock substrates used by these species (Herbst 1994). Once the lake elevation recedes below an elevation of $1294.5 \mathrm{~m}$, most rock substrates are uncovered. This happened in July 2010 and lasted for about 6 months. It happened again more recently in June 2013, and lake elevation has remained below $1294.5 \mathrm{~m}$ through 2015.

Effects of diminished prey availability for migratory waterbirds using Lake Abert has likely had a substantial adverse effect on several waterbird species, especially Eared Grebes, various gulls, and Red-necked and Wilson's Phalaropes (Table 2). These 3 groups of birds feed extensively in open water and are known to feed on brine shrimp (Boula 1986, Jehl 1988, Roberts 2013). When alkali flies are numerous, fly larvae and pupae are also present at the lake surface and are likely eaten by these birds. Because fly larvae and pupae are larger than brine shrimp, they are likely preferred.

During the recent high-salinity events, other waterbirds, such as American Avocets and Black-Necked Stilts, were affected to a lesser degree than the Eared Grebes, gulls, 
and Red-Necked and Wilson's Phalaropes. This was likely due to their ability use benthic prey, especially fly larvae and pupae that were present in the pool created by the springs near the northeastern shore. The fact that modest numbers of waterbirds still utilized Lake Abert under the adverse salinity conditions in 2014 and 2015 attests to their adaptability. During the recent high-salinity events at the lake and resultant reductions in Artemia and Ephydra populations, some birds might have been able to switch to alternative prey. For example, Snowy Plovers (Charadrius nivosus), which are small shorebirds, feed primarily on insects, especially alkali flies, when inland (Purdue (1976). When alkali flies were scarce at Lake Abert, Snowy Plovers may have fed on Bledius sp. beetles, which are a known prey item for these birds on the Great Salt Plains of Kansas (Purdue 1976).

In 2014 and 2015, other lakes in the northwest corner of the Great Basin used by migrating waterbirds were also dry, including all of the lakes in south central Oregon (i.e., Goose, Harney, Summer, and Warner Lakes). Consequently, this region was unable to support waterbird populations as it previously has done. The fate of these birds is unknown, but lack of food necessary for building premigratory energy reserves is likely to be detrimental at individual and population levels (Colwell 2010). Worldwide, degradation of stopover sites like Lake Abert is an important factor contributing to the decline of shorebirds (Morrison et al. 2001, 2006, Thomas et al. 2006, Bart et al. 2007, Andres et al. 2012).

The future of Lake Abert as a productive ecosystem that provides crucial seasonal habitat for migratory waterbirds depends on climate and amount of water that is removed upstream. Currently Oregon has no minimum instream flow restrictions on diversions, so instream flow can be greatly affected when inflows are low and irrigation demands are high. However, there are opportunities to ensure that environmental water needs are met in a way that does not have serious adverse consequences for rural communities dependent on water (Bastasch 2006). For example, a small fee could be attached to water use on a per-unit-volume basis, which would reduce overuse, help fund water monitoring, and support water purchases to enhance instream flows.

\section{ACKNOWLEDGMENTS}

We gratefully acknowledge the assistance and encouragement of the following people who helped us in varying ways. Kathy Larson, Klamath Falls, Oregon, provided valuable editorial comments. Lynn Kreuz, Portland, Oregon, prepared wonderful home-cooked meals for us while we were at Lake Abert. Martin St. Louis, Oregon Department of Fish and Wildlife, Summer Lake, provided evaporation data from Summer Lake, Oregon. Josh Rasmussen, U.S. Fish and Wildlife Service, Klamath Falls, Oregon, provided helpful editorial comments and prepared the Spanish resumen. Steve Sheehy, Klamath Falls, Oregon, assisted us with lake-level measurements and with water and biotic sampling. Steve VanDenburgh, Carson City, Nevada, shared stories and data from his research at the lake in the 1960s and assisted with lake-level and salinity measurements. Trent Seager, Oregon State University, provided helpful review comments, contributed lake-level and bird abundance data, and assisted in other ways. David Herbst, University of California Sierra Nevada Aquatic Research Laboratory, provided salinity and lake-level data and greatly helped us understand how salinity affects the biota. We are also grateful to members of the East Cascade Audubon Society who traveled long distances to count birds at Lake Abert. Their efforts have contributed to a better understanding of the role birds play in that ecosystem.

\section{Literature Cited}

ALLISON, I.S. 1982. Geology of pluvial Lake Chewaucan. Studies in Geology, Number 11. Oregon State University Press, Corvallis, OR.

Andres, B., P. Smith, R. Morrison, C. Gratto-trevor, S. Brown, AND C. FriIs. 2012. Population estimates of North American shorebirds, 2012. Wader Study Group Bulletin 119:178-194.

Aronesty, E. 2013. Comparison of sequencing utility programs. Open Bioinformatics Journal 7:1-8.

Asao, M., H.C. Pinkart, and M.T. Madigan. 2011. Diversity of extremophilic purple phototrophic bacteria in Soap Lake, a Central Washington (USA) soda lake. Environmental Microbiology 13:2146-2157.

Bart, J., S. Brown, B. Harrington, and R. Morrison. 2007. Survey trends of North American shorebirds: populations declines or shifting distributions? Journal of Avian Biology 38:73-82.

Bastasch, R. 2006. The Oregon water handbook: a guide to water and water management. Oregon State University Press, Corvallis, OR. 
BoulA, K.M. 1986. Foraging ecology of migrant water birds, Lake Abert, Oregon. Master's thesis, Oregon State University, Corvallis, OR.

Caporaso, J.G., J. Kuczynski, J. Stombaugh, K. Bittinger, F.D. Bushman, E.K. Costello, N. Fierer, A.G. Pena, J.K. Goodrich, J.I. Gordon, et al. 2010. QIIME allows analysis of high-throughput community sequencing data. Nature Methods 7: 335-336.

Case, H.L., III, J. Boles, A. Delgado, T. Nguyen, D. Osugi, D.A. Barnum, D. Decker, S. Steinberg, S. SteinberG, C. Keene, et AL. 2013. Salton Sea ecosystem monitoring and assessment plan: U.S. Geological Survey Open-File Report 2013-1133.

Castro-Mejia, J., T. Castro-Barrera, L.H. HernandezHernandez, J.L. Arredondo-Figueroa, G. CasTRO-MEJIA, AND R. DE LARA-ANDRADE. 2011. Effects of salinity on the growth and survival in five Artemia franciscana (Anostraca: Artemiidae) populations from Mexico Pacific Coast. International Journal of Tropical Biology 59:199-206.

Caumette, P. 1993. Ecology and physiology of phototrophic bacteria and sulphate-reducing bacteria in marine salterns. Experientia 49:473-481.

Cohen, M.J. 2014. Hazard's toll: the costs of inaction at the Salton Sea. Pacific Institute. http://pacinst.org/ publication/hazards-toll

Colwell, M.A. 2010. Shorebird ecology, conservation and management. University of California Press, Berkeley, CA.

Colwell, M.A., AND J.R. Jehl. 1994. Wilson's Phalarope (Phalaropus tricolor). In: A. Poole and F. Gill, editors, The Birds of North America Online. Cornell Lab of Ornithology, Ithaca, NY. http://bna.birds.cornell .edu/bna/species/083

CONTE, F.P., AND P.A. ConTe. 1988. Abundance and spatial distribution of Artemia salina in Lake Abert, Oregon. Hydrobiologia 158:167-172.

Dadheech, P.K., G. Glockner, P. Casper, K. Kotut, C.J. Mazzoni, S. Mbedi, and L. Krienitz. 2013. Cyanobacterial diversity in the hot spring, pelagic and benthic habitats of a tropical soda lake. FEMS Microbiological Ecology 85:389-401.

Dassarma, S., and P. DasSarma. 2012. Halophiles. In: eLS. John Wiley \& Sons, Ltd., Chichester, England.

DeSantis, T.Z., P. Hugenholtz, N. Larsen, M. Rojas, E.L. Brodie, K. Keller, T. Huber, D. Dalevi, P. Hu, AND G.L. ANDERSEN. 2006. Greengenes, a chimerachecked 16S rRNA gene database and workbench compatible with ARB. Applied and Environmental Microbiology 72:5069-5072.

Dimitriu, P.A., H.C. Pinkart, B.M. Peyton, and M.R. Mormile. 2008. Spatial and temporal patterns in the microbial diversity of a meromictic soda lake in Washington State. Applied and Environmental Microbiology 74:4877-4888.

Gajardo, G.M., and J.A. Beardmore. 2012. The brine shrimp Artemia: adapted to critical life conditions. Frontiers in Physiology 3(185):1-8.

Garcia, C.M., AND F.X. Niell. 1991. Burrowing beetles of the genus Bledius (Staphylinidae) as agents of bioturbation in the emergent areas and shores of an athalassic inland lake (Fuente de Piedra, southern of Spain). Hydrobiologia 215:163-173.

Gerdes, G., H. Porada, and H. Bouougri. 2008. Biosedimentary structures evolving from the interaction of microbial mats, burrowing beetles and the physical environment of Tunisian coastal sabkhas. Senckenbergiana Maritima 38:45-58.

Grant, S., W.D. Grant, B.E. Jones, C. Kato, and L. Li. 1999. Novel archaeal phylotypes from an East African alkaline saltern. Extremophiles 3:139-145.

Hammer, U.T. 1986. Saline lake ecosystems of the world. Junk, Dordrecht, Netherlands.

Herbst, D.B. 1988. Comparative population ecology of Ephydra hians Say (Diptera: Ephydridae) at Mono Lake (California) and Lake Abert (Oregon). Hydrobiologia 158:145-166.

Herbst, D.B. 1994. Aquatic ecology of the littoral zone of Lake Abert: defining critical lake levels and optimum salinity for biological health. Report prepared for the Oregon Department of Fish and Wildlife and the U.S. Bureau of Land Management, August 1994.

Herbst, D.B. 2001. Gradients of salinity stress, environmental stability and water chemistry as a templet for defining habitat types and physiological strategies in inland salt waters. Hydrobiologia 466:209-219.

Herbst, D. 2014. From mountains to the saline lakes of the Great Basin: ecosystems at risk. Page OOS49 in D.B. Herbst and S. Mortenson, editors, From Mountains to the Saline Lakes of the Great Basin: Ecosystems at Risk. Ecological Society of America, Sacramento, CA. http://eco.confex.com/eco/2014/webpro gram/session9735.html

Herbst, D.B., and T.J. Bradley. 1989. Salinity and nutrient limitations on the growth of benthic algae from two alkaline lakes of the western Great Basin (USA). Journal of Phycology 25:673-678.

Herbst, D.B., and R.W. Castenholz. 1994. Growth of the filamentous green alga Ctenocladus circinnatus (Chaetophorales, Chlorophyceae) in relation to environmental salinity. Journal of Phycology 30:588-593.

Herbst, D.B., R.B. Medhurst, I.D. Bell, and G. ChisHOLM. 2014. Walker Lake-terminal lake at the brink. Lakeline, Fall 2014:11-14.

Herlemann, D.P., M. Labrenz, K. Jürgens, S. BertilsSON, J.J. WANIEK, AND A.F. ANDERSSON. 2011. Transitions in bacterial communities along the $2000 \mathrm{~km}$ salinity gradient of the Baltic Sea. ISME Journal 5:1571-1579.

Humayoun, S.B., N. Bano, and J.T. Hollibaugh. 2003. Depth distribution of microbial diversity in Mono Lake, a meromictic soda Lake in California. Applied and Environmental Microbiology 69:1030-1042.

JAVOR, B. 1989. Hypersaline environments: microbiology and biogeochemistry, Springer Verlag, Berlin.

JenL, J.R. 1988. Biology of the Eared Grebe and Wilson's Phalarope in the non-breeding season: a study of adaptations to saline lakes. Studies in Avian Biology 12.

JEHL, J.R. 1994. Changes in saline and alkaline lake avifaunas in western North America in the past 150 years. Studies in Avian Biology 15:258-272.

JEHL, J.R. 1999. Population studies of Wilson's Phalaropes at fall staging areas, 1980-1997: a challenge for monitoring. Waterbirds: The International Journal of Waterbird Biology 22:37-46.

Jellison, R., W.D. Williams, B. Timms, J. Alcocer, and N.V. Aladin. 2008. Salt lakes: values, threats and future. Pages 94-110 in N. Poluninm, editor, Aquatic ecosystems. Cambridge University Press. http:// dx.doi.org/10.1017/CBO9780511751790.010

JENSEN, M.E. 2010. Estimating evaporation from surface waters. CSU/ARS Evapotranspiration Workshop, 
Fort Collins, CO. 15 March 2010. http://www.ccc .atmos.colostate.edu/ET_Workshop/ET_Jensen/ET _water_surf.pdf

Jeppesen, E., S. Brucet, L. Naselli-Flores, E. Papastergiadou, K. Stefanidis, T. Noges, P. Noges, J. Attayde, T. Zohary, J. Coppens, ET AL. 2015. Ecological impacts of global warming and water abstraction on lakes and reservoirs due to changes in water level and related changes in salinity. Hydrobiologia 750:201-227.

Keister, G.P., JR. 1992. The ecology of Lake Abert: analysis of further development. Special Report, Oregon Department of Fish and Wildlife, Salem, OR, April 1992.

Lanzén, A., A. Simachew, A. Gessesse, D. Chmolowska, I. Jonassen, AND L. ØVREÅs. 2013. Surprising prokaryotic and eukaryotic diversity, community structure and biogeography of Ethiopian soda lakes. PLOS ONE 8(8):72577.

LESTERHUis, A.J., AND R.P. Clay. 2010. Conservation plan for Wilson's Phalarope (Phalaropus tricolor). Version 1.1. Manomet Center for Conservation Sciences, Manomet, MA. http://www.whsrn.org/sites/default/ files/file/Wilsons_Phalarope_Conservation_Plan_10_ 02-28.

Licciardi, J.M. 2001. Chronology of latest Pleistocene lake-level fluctuations in the pluvial Chewaucan basin, Oregon, USA. Journal of Quaternary Science 16:545-553.

Mesbah, N.M., S.H. Abou-El-Ela, and J. Wiegel. 2007. Novel and unexpected prokaryotic diversity in water and sediments of the alkaline, hypersaline lakes of the Wadi an Natrun, Egypt. Microbial Ecology 54:598-616.

Micklin, P. 2007. The Aral Sea disaster. Annual Review of Earth and Planetary Sciences 35:47-72.

Moore, J.N. 2016. Recent desiccation of western Great Basin saline lakes: lessons from Lake Abert, Oregon. U.S.A. Science of the Total Environment 554555:142-154.

Morrison, R., Y. Aubry, R. Butler, G. Beyersbergen, G. Donaldson, C. Gratto-Trevor, P. Hicklin, V. Johnston, And R. Ross. 2001. Declines in North American shorebird populations. International Wader Study Group Bulletin 94:34-39.

Morrison, R., B. McCaffery, R. Gill, S. Skagen, S. Jones, G. Page, C. Gratto-Trevor, and B. Andres. 2006. Population of North American shorebirds, 2006. Wader Study Group Bulletin 111:66-84

Ochsenreiter, T., F. Pfeifer, and C. Schleper. 2002. Diversity of Archaea in hypersaline environments characterized by molecular-phylogenetic and cultivation studies. Extremophiles 6:267-274.

[OWRD] Oregon Water Resources Department. 1989. Goose and Summer Lakes basin report. Salem, OR.

Oring, L.W., L. NeEL, AND K.E. ORING. 2009. Intermountain West Regional Shorebird Plan. U.S. Shorebird Conservation Plan. http://www.shorebirdplan .org/wp-content/uploads/2013/01/IMWEST4.pdf

Pagaling, E., H. Wang, M. Venables, A. Wallace, W.D. Grant, D.A. Cowan, B.E. Jones, A. Ventosa, and S. HeAphy. 2009. Microbial biogeography of six salt lakes in inner Mongolia, China, and a salt lake in Argentina. Applied and Environmental Microbiology 75:5750-5760.

Phillips, K.N., and A.S. VanDenburgh. 1971. Hydrology and geochemistry of Abert, Summer, and Goose Lakes, and other closed-basin lakes in south-central Oregon. Closed-Basin Investigations, U.S. Geological Survey Professional Paper 502-B.

Pohl, K.A., K.S. Hadley, and K.B. Arabas. 2002. A 545year drought reconstruction for central Oregon. Physical Geography 23:302-320.

Purdue, J.R. 1976. Adaptions of the Snowy Plover on the Great Salt Plains, Oklahoma. Southwestern Naturalist 21:347-357.

Risley, J.C., AND M.W. GanNETT. 2006. An evaluation and review of water-use estimates and flow data for the Lower Klamath and Tule Lake National Wildlife Refuges, Oregon and California. U.S. Geological Survey Scientific Investigations Report 2006-5036.

Roberts, A.J. 2013. Avian diets in a saline ecosystem: Great Salt Lake, Utah, USA. Human-Wildlife Interactions 7:158-168.

Russell, I.C. 1884. A geological reconnaissance in southern Oregon. Pages 435-462 in U.S. Geological Survey 4th Annual Report.

Sorokin, D.Y., T. Berben, E.D. Melton, L. Overmars, C.D. Vavourakis, and G. MuYzer. 2014. Microbial diversity and biogeochemical cycling in soda lakes. Extremophiles 18:791-809.

Thomas, G.H., R.B., LANCTOT, and T. SzÉKely. 2006. Can intrinsic factors explain population declines in North American breeding shorebirds? A comparative analysis. Animal Conservation 9:252-258.

TuRK, L.J. 1970. Evaporation of brine: a field study on the Bonneville Salt Flats, Utah. Water Resources Research 6:1209-1215.

[USDA] United States Department of Agriculture. 2006. Lake Abert - 17120006, 8-Digit Hydrologic Unit Profile. Final, February 2006. http://www.nrcs .usda.gov/Internet/FSE_DOCUMENTS/nrcs142p2 040054.pdf.

VAnDEnburgh, A.S. 1975. Solute balance at Abert and Summer Lakes, south-central Oregon. Closed-Basin Investigations. U.S. Geological Survey Professional Paper 502-C.

Williams, W.D. 2000. Dryland lakes. Lakes and Reservoirs: Research and Management 5:207-212.

Williams, W.D., A. Boulton, and R.G. TaAfFe. 1990. Salinity as a determinant of salt lake fauna: a question of scale. Hydrobiologia 197:257-266.

Wurtsbaugh, W.A. 2014. Management of the Great Salt Lake ecosystem: water, economic values and competing interests. Utah State University Watershed Science Faculty Publication 594. http://digitalcommons.usu.edu/wats facpub/594.

Wurtsbaugh, W.A., C. Miller, S. Null, P. Wilcock, M. HaHENBERGER, AND F. Howe. 2016. Impacts of water development on Great Salt Lake and the Wasatch Front. Watershed Sciences Faculty Publications. Paper 875. http://digitalcommons.usu.edu/wats_facpub/875

Received 1 December 2015 Accepted 19 July 2016 